\title{
Beyond a 35 Approach to Marketing \\ Island Nations? Destination Marketing \\ and Experiences from Timor-Leste
}

\section{Sara Currie}

Before my first trip to Timor-Leste in 20 I I, I visited a local travel agent in Melbourne to see if I could get a comparative rate on flights to Dili. She asked me if I planned to stop by Mumbai; or perhaps I wanted to visit Goa? I realized she was looking at fares for Delhi. I clarified that I was visiting Timor-Leste, not India, and she responded with a blank stare. "It's close to Indonesia," I said. "Just north of Darwin." She had no idea where I was talking about.

When I landed in Dili, Timor-Leste's capital, I was impressed by the small, shed-like terminal and the huge "welcome" sign above it. I was greeted by the intermingled smells of sandalwood, sewerage, and sweat from the tropical humidity. At the airport, I found no further signage, no tourism brochures, and certainly no visitor information center. I jumped in a taxi and hoped for the best. During that first visit, I simultaneously loved the beachside esplanade, was horrified by the high prices of a United Nations-inflated economy, and was enchanted by the locals. I visited Maubisse, a mountain township three hours south of Dili, and was surprised at how the beautiful, rural districts contrasted with the "thriving" capital. I got food poisoning, avoided dengue fever, and never once felt unsafe. The nation clearly had huge potential for niche cultural and nature-based tourism but had very few actual tourists. Was Timor-Leste the next undiscovered paradise?

The half-island of Timor-Leste is located six hundred and forty kilometers (398 miles) northwest of Darwin, Australia, and a hundred kilometers (62 miles) southwest of Java, Indonesia. A former Portuguese colony, Timor-Leste was invaded by Indonesia in 1975. The brutal occupation lasted twenty-four years, during which time conflict-related deaths

The Contemporary Pacific, Volume 30, Number 2, 438-459

(C) 2018 by University of Hawai' $i$ Press 
are estimated to have reached nearly two hundred thousand (CAVR 2005). After the downfall of the Suharto regime in 1998, the Timorese people voted for their independence and, after a United Nations transitional administration, Timor-Leste became an independent nation on 20 May 2002.

Today the population of Timor-Leste is estimated at nearly I.3 million and is overwhelmingly Catholic at 97.6 percent (CIA 20I7). Though partially dependent on agriculture-predominantly coffee and ricethanks to vast offshore resources of oil and natural gas, Timor-Leste has the second-highest petroleum dependency in the world at 95 percent of state revenues (La'o Hamutuk 20I3). In an attempt to remedy this imbalance, tourism has been strongly promoted as a useful vehicle for economic growth and much-needed diversification. The nation is naturally beautiful, safe, and peaceful; however, despite government attempts to grow tourism to Timor-Leste, recent data suggest that the nation receives less than fifty thousand genuine leisure tourists per year (Timor-Leste Department of Immigration 2017).

For five years I worked in Timor-Leste, first as a marketing manager for the Office of the President, then later as an advisor for the Ministry of Tourism and a consultant for the Asia Foundation, a nongovernmental organization ( $\mathrm{NGO}$ ). Over those years, it became apparent that there are many reasons that tourism to the Pacific Island nation has been dormant since independence: limited infrastructure, poor accessibility, and the high cost to reach and travel within Timor-Leste are coupled with a lack of "destination marketing" both to promote the nation internationally and to overcome any negative perceptions still lingering from its turbulent past. The government of Timor-Leste is committed to growing tourism; however, destination marketing has been limited, despite continued attempts from successive governments and NGOs. ${ }^{1}$

Given that Timor-Leste is only now beginning to promote itself to visitors, the nation has a unique opportunity to learn from the successes and mistakes of other islands, particularly in the Pacific. Indeed, there are significant ethical and moral considerations when promoting a new island destination for tourism. Marketing has a vital role to play in the representation of any destination, since the way in which a destination is represented can have a profound impact on local communities with respect to the type of tourism and tourists that the place attracts. In her study of tourism in New Caledonia, Anne-Marie d'Hauteserre argued that Indigenous people rarely have an opportunity to resist or to counter how they 
are portrayed (2OII). Image, identity, and representation, when socially constructed by various stakeholders, can both generate and powerfully maintain inequality and socioeconomic impoverishment.

This article draws on my years working in the tourism industry in Timor-Leste as well as my doctoral research conducted from $20 \mathrm{I} 2$ to 20I6. Throughout my research, I explored the question of whether it was possible to develop a marketing campaign that avoids the commodification of paradise and instead represents an island destination as part of a culturally significant landscape. I argue that while the trope of "paradise" and the promotion of sun, sea, and sand (coined "the $3 \mathrm{~s}$ ") may be appealing in glossy magazines and destination websites, it raises an important question: At what cost is paradise bought and sold? Through my research in Timor-Leste I came to realize that a destination marketing campaign should begin by understanding the "sense of place" as experienced by local residents. This allows destination marketing to provide a meaningful representation of how stakeholders perceive their "place" and "home."

My work builds on a recent body of scholarship that examines Indigenous ownership of and meaningful participation in tourism. This includes work in New Caledonia (d'Hauteserre 20II); in the Trobriand Islands (MacCarthy 2016); and also among Indigenous groups in a variety of settler-colonial societies (Bunten 2008; Stronza 2008; Weaver 20I0; Lloyd and others 20I5; Carr, Ruhanen, and Whitford 20I6). Collectively, the key insights of these works provide a focus on the potential benefits of tourism to local stakeholders, including income-generating opportunities, skills development, and cultural conservation. While the majority of this work focuses on tourism operators, my research examines the first stage of tourism development: that of marketing and how Indigenous groups can be involved in the ownership of a campaign from its inception.

To this end, my research involved ninety-four interviews with fifty-six tourism stakeholders in Timor-Leste, through which I began to better understand the sense of place that they attributed to their island, and, more importantly, the ways in which they were for these representations and their "island paradise" to be promoted for tourism. ${ }^{2}$ In order to obtain as broad a consensus as possible, a wide range of tourism stakeholders were included in the interview process, from the president and prime minister to small tour operators and tourism students. Stakeholder focus groups were also conducted to provide a forum for discussion and debate. While the final destination marketing campaign that was developed did, in fact, reinforce some of the stereotypes we had hoped to avoid, as this article 
details, it ultimately met our overriding aim: to develop a marketing campaign for Timor-Leste led by Timorese stakeholders. It portrayed TimorLeste not as an island paradise, indistinguishable from its neighbors, but as a nation that is unpolished, genuine, and, after a long occupation, ready to welcome tourists.

\section{Ethical Considerations of Marketing an EMERging Island Nation}

The marketing of island destinations is set within a wider discourse of tourism promotion that is aimed at the packaging of "imagined" people, places, and experiences to foreign tourists (Rogal 20I2) and that draws on existing social and cultural elements within the destination to develop a brand or identity (Cornelissen 2005). At the same time, tourism marketers also fashion new narratives to attract tourists by, for example, both adopting local myths of the place and people and helping to perpetuate them (Amoamo 2007). It follows, then, that destination marketers hold power not only over tourists but also over the communities and landscapes they promote.

When promoting developing nations, Charlotte Echtner and Pushkala Prasad suggested that there are three distinct patterns of representation, all of which are grounded in colonial typologies (2003). The first, the "myth of the unchanged," portrays destinations as "ripe for discovery," where modern-day tourists can relive the journeys and experiences of ancient explorers. Besides invoking stereotypical images of poverty and backwardness, the "Third World" is conceived of as being past its prime; "modern First World tourists are encouraged to feast on the past built glories of these Third World destinations, for apparently these features-and not their present-day state-are the most worthy of their gaze" (Echtner and Prasad 2003, 67I).

The second myth, the "myth of the unrestrained," takes tourists to luxuriant lands where nature is pristine, the Indigenous people are friendly, and the resorts cater to every desire. This myth is more about exploitation than exploration, and local inhabitants assume a passive role, being both serving and submissive. Finally, the third pattern, the "myth of the uncivilized," builds on a trope that represents tourism as an expedition "beyond the furthest frontiers" of civilization, where the landscape is savage and inhospitable (Echtner and Prasad 2003, 675).

For island nations, the "myth of the unrestrained" means that many 
people are forced to work to retain the appearance of so-called pristine natural beauty. And selling this myth of paradise to Western tourists oftentimes comes at the expense of island degradation-through, for example, heavier demands on water supply, clearing land that would be otherwise left for other purposes, and increased waste disposal requirements. The tourism industry continues to portray island destinations as "paradise," "unspoiled," and "sensuous," while often there is abject poverty just beyond the hotel or sightseeing bus. Poverty is not conducive to representations of paradise and so must remain absent from the tourism marketing representations (Echtner and Prasad 2003; Tamaira 2016). In the promotion of paradise, exploitative relations between host and guest are obscured, and imagery instead portrays a world of abundance and luxury where fresh towels, flowers, and fruit appear in hotel rooms as if by magic (Alexeyeff 20I6).

A further challenge in promoting paradise is the sense of substitutability that is created by some tourism campaigns. While many island tourism campaigns advertise and make generic claims about sandy beaches and a laidback lifestyle, these claims are not unique to a particular nation (Dinnie 2008; Harrison-Walker 20II); according to Nigel Morgan, Annette Pritchard, and Rachel Piggot (2003), such "wallpaper" advertising renders all island destinations as indistinguishable from one another. Marketing island destinations based solely on images of sun, sea, and sand-the $3 \mathrm{~s}$ approach-leaves them susceptible to competition and shifting market conditions. For example, when events such as natural disasters, political problems, or price changes occur in one destination, tourists can easily experience a similar type of holiday in another island destination (Pratt 20I3). Because the ways in which they are marketed generates a kind of island substitutability, these countries risk becoming interchangeable commodities, driven by competition to lower prices and thus forced to attract more tourists who spend less money individually (Olins 2005).

While an extensive literature outlines the implications and risks of marketing developing island destinations, there is limited research on the strategies to promote authentic tourism representations and discourage cultural stereotypes. Thus, attention now needs to be turned to the forms of counter-colonial discourse needed to resist such representations (Yang 20II; Echtner and Prasad 2003).

A number of authors highlight the imperative to involve internal stakeholders in the destination-marketing process (Santos and Campo 20I4; Sinclair-Maragh and Gursoy 2015). Indeed, tourism is often seen as a 
catalyst for change in the ways that people perceive themselves and others through the promotion and packaging of an island's natural environment, culture, and history. It is therefore vital that tourism marketing reflects the unique cultural heritage and historical traits of the destination through careful consultation with community leaders. Maria Amoamo suggested taking a more holistic approach to recognize the diversity of Indigenous identities and create richer tourism experiences (2007). Similarly, Edson Santos and María Campo argued that a greater use of local culture and history can promote the destination's core values, personality, and unique characteristics and, in doing so, provide a travel experience that cannot be compared with other places (20I4). Local communities can therefore be considered one of the most critical tourism stakeholders. In marketing island destinations, recent scholarship suggests that residents should not be convinced to endorse tourism but should rather be treated as stakeholders whose attitudes and interests help guide tourism development and promotion (Sinclair-Maragh and Gursoy 2015). For island destinations, a prolonged emphasis on the $3 \mathrm{~s}$ product results in less attention to developing the cultural and historical attributes of the country and can fail to establish a long-standing emotional connection with the consumer (Roberts and Lewis-Cameron 2010).

This analysis of the colonial-style tourism marketing and potential counter-colonial strategies suggests that marketing an island nation such as Timor-Leste requires actively involving the nation's tourism stakeholders in ways that would provide both ownership and meaningful participation. From a marketing perspective, this requires a strong understanding of the country's tourism attributes-beyond its $3 \mathrm{~s}$ features-and a harnessing of the unique elements of the destination to create a lasting, emotional connection with the consumer.

The next section examines the desired representation of paradise, culture, people, and local personality, as articulated by Timor-Leste's tourism stakeholders. Stakeholders were identified through purposive sampling to ensure representation of the private sector, including hotels, travel agencies, and airlines, as well as government officials, NGOs involved in tourism, and education providers. Participant nationality was also an important distinction, with stakeholders selected to include foreign expatriates living in Timor-Leste while maintaining a predominance of Timorese nationals. My role was to listen, record, and undertake the almost impossible task of reconciling views and arriving at a consensus of what should be included in an achievable marketing campaign. Following the discussion 
of the desired representation, I present a short marketing campaign that I developed with the stakeholder contingent and government of TimorLeste. It depicts the possibilities we saw for an ethical and stakeholder-led approach to marketing Timor-Leste.

\section{The Promotion of Paradise}

In 20I 2, while working at the Office of the President, I began my doctoral research with the aim of developing a marketing campaign for TimorLeste. The central aim of my research was to avoid the commodification of paradise and the use of a $3 \mathrm{~s}$ approach to destination marketing. Therefore, it was essential to ask stakeholders whether paradise could be incorporated into the campaign, while still depicting the nuances and rich cultural landscape of the destination. As an island nation, beaches are one of Timor-Leste's preeminent assets and an important selling point for leisure tourists. In fact, a survey conducted by the Asia Foundation found that "beach leisure" is the most common activity undertaken by tourists while visiting Timor-Leste (Rajalingam 20I4). Therefore, while beaches could not be omitted from marketing, it was important that marketing did not simply become a portrayal of paradise that simplified the culture and nuances of Timor-Leste as a destination.

Further, although the government currently markets "white sand beaches" in tourism brochures and their Strategic Development Plan $20 I I-2030$ (Timor-Leste Government 20II), the reality is that these few beaches are the exception in Timor-Leste and are hard to reach. If driving to the stunning white-sand beaches located on Jaco Island at the very eastern tip of the country, the Timor-Leste Lonely Planet guide suggests, "You may well feel like you're going to the end of the Earth" (Cocks 20I I, 72). While the beaches closer to Dili, along the north coast, are often clean and inviting, they lack the white sands and clear waters to compete with other Pacific Islands or Australia. A stakeholder working in private-sector tourism explained to me: "When they [the government] promote pictures, it is only the beautiful images they take at Tutuala [at the extreme eastern end of the island], the beach, the diving. And that is perfect. But then people come here thinking everything is beautiful, then they [are] disappointed when they find the roads and accommodation are not spot on" (interview, Tibar, Jan 20I4).

Several stakeholders suggested that Timor-Leste has an opportunity to diverge from a stereotypical island representation and, in doing so, to 
distinguish itself from other island destinations. In many cases, tourists are provided a first glimpse of a destination through pre-packed stereotypes portrayed in tourism brochures and travel agency windows (Bunten 2008). Since many of Timor-Leste's natural attractions are also rich in historical and cultural heritage, a depiction of the depth and story behind the nation's natural environment and people can provide a more compelling basis for destination marketing than just images of white sand beaches.

The development of the Nino Konis Santana National Park, for example, was an important milestone for preservation and tourism in TimorLeste. Established in August 2007 and spanning a total of I23,024 hectares (304,000 acres), the park includes both land and sea and is home to ancient cave paintings and ancestral tombs, alongside significant bird life. This is the first national park in Timor-Leste and is now comanaged by local communities working in partnership with the Timorese government (Conversation International 20I8). As a stakeholder working for a local NGO suggested: "Traditionally, as Timorese, there has been some pattern, traditional framework, [for] how to manage the natural resources. There is local knowledge on how to protect beach, the marine biodiversity, special spaces. There's always specific story behind any mountain, any lake, any beach in Timor-Leste. We tried to explore that if a lake has special meaning to society, we try to grow the tourism value around that" (interview, Aileu, Dec 20I3).

In building the marketing campaign, it was agreed that the campaign should minimize the impression of "passive sun-lust" and instead depict the Timor-Leste coastal environment as part of a landscape that is culturally and historically significant to its people. It was hoped that this would, in turn, help attract tourists looking for a more meaningful travel experience as opposed to just a beach holiday. We therefore decided to include only one image of a beach in a marketing campaign made up of twenty images. While it was important to show that the nation's beaches were indeed appealing, it was essential they were not the focus of our island marketing campaign.

\section{The Promotion of Culture}

If beaches were not to be the focus of our marketing campaign, then a strong understanding of how best to portray Timorese culture became vital. A number of stakeholders reinforced that, while it was important to promote the culture of Timor-Leste, it had to be done in a manner that 
avoided commodifying and representing a stylized, staged version of the destination's cultural attributes.

While the nation's Strategic Development Plan 201 I-2030 argues that "with our traditional culture, the living history of our rural communities ... Timor-Leste is able to provide visitors with a memorable experience" (Timor-Leste Government 20I I, I42), there is no planning document currently available that details how Timorese culture and its traditions will be made accessible to tourists. The risk is that, by directing cultural traditions solely toward tourism, complex cultural heritages can be simplified, homogenized, packaged, and in some cases, trivialized (Engelhardt 2005). As other research has shown, this kind of marketing can pressure local communities to maintain a "timeless" appeal in their cultural performances for authenticity-seeking international tourists, resulting in cultural commodification and a loss of "authentic meaning" (Yang and Wall 2009; Buzinde and others 2010; Rogal 2012).

While experiencing Timorese cultural traditions could prove fascinating for many tourists, there was consensus among the stakeholders I interviewed that a tourism industry that offered "packages" based on Timorese cultural traditions could, in fact, have a damaging impact on the nation's culture. Further, the people of Timor-Leste have a complex history, and across the centuries the nation's culture has evolved through Portuguese colonization, World War II, the Indonesian invasion, and the United Nations mission up until today's transitional era of independence. It became apparent to me throughout the interview process that the last thing the Timorese people want is another "invasion" of foreigners. A Timorese stakeholder working for a local NGO explained: "Of course, culture is always influenced by other cultures; by Portugal, Indonesians, the United Nations, modernity and so on. But the idea in here is to differentiate what has originated in here, and what is from outside" (interview, Dili, Nov 2013). One of the risks of promoting tourism and inviting more people to the country is the detrimental impact this may have on Timorese culture: "Everywhere, when there is a sacred place visited by many people frequently, it will erode the sacred place. If everyone is allowed to see and visit, when you open, without any control, it can be desacralized" (interview, Aileu, Dec 2013).

The Timorese way of life is very different from the West and, one could therefore argue, very interesting to visitors. Timor-Leste is a predominantly Catholic nation; however, long before Portuguese settlement, Timorese people were animists and engaged in an ancestor worship system that 
governed norms, values, morals, and ideologies. These traditional rituals are today still practiced across Timor-Leste, either alongside or in combination with Catholicism, making the cultural heritage of Timor-Leste diverse and different from all others. Timorese culture is underpinned by a very special relationship with the lulik-a Tetum word that is translated as "forbidden," "holy," or "sacred." ${ }^{3}$ Lulik refers to the spirit of the ancestors and acts as a philosophy that ensures "peace and tranquility" for Timorese society, which "can be achieved through the proper balance between differing and opposing elements" (Trindade 20I2, I). For local Timorese, the lulik is an important part of everyday life. East Timorese culture places great value on sacred houses or umalulik, which often store ancient ancestral heirlooms and are used for ceremonies and cultural traditions. Stakeholders therefore urged that, while it is important to promote culture, it must be promoted through a detailed understanding of its genuine and unique attributes, as opposed to being simply "manufactured" for tourist consumption. One education stakeholder explained: "To show the true Timor-Leste, we go back to our culture, and the traditions of our life. This is the important thing to promote; to show internationally around the world" (interview, Dili, Dec 2013). Another important and widely practiced custom in Timor-Leste is the traditional weaving or making of tais cloth. Traditionally, women weave tais on simple back-strap looms. Tais are used in important ceremonies and burials. Also, for such a geographically small nation, Timor-Leste offers significant cultural diversity between districts. This is also demonstrated by today's highly multilingual society, which has at least sixteen first languages.

A stakeholder working in private-sector tourism explained that the opportunity to experience the depth of cultural traditions is an important attraction to promote to tourists. It is not about merely "seeing" the cultural traditions, for example in a museum, but also "experiencing" them firsthand. Timor-Leste may thus appeal to travelers wanting to really connect with a culture and local communities and to enjoy a more native experience. He explained: "This is an ideal place for people to have a grassroots experience; stay in the community, experience something local, go fishing, try local food, see something of local culture, the natural landscapes" (interview, Baucau, Dec 20I3). While conducting this research, it became apparent to me that many Timorese are very proud of their culture. Locals are often keen to demonstrate their local customs and traditions, which are rich, fascinating, and also unique to Timor-Leste. As one local tourism stakeholder explained: "People are interested to see 
this because some other places they don't have these things. We are very special" (interview, Dili, Nov 2013).

When discussing a marketing perspective with Timor-Leste's tourism stakeholders, we agreed that, when promoting Timor-Leste internationally, the nation's culture should be promoted through a detailed understanding of its unique attributes, as opposed to promoting a packaged and manufactured culture simply to appeal to Western tourists. This was implemented though the careful selection of images that we felt presented culture as an everyday experience as opposed to something that is "staged" or put on show for visitors.

\section{The Promotion of People}

As a newly independent nation still emerging from occupation and civil war, Timor-Leste as a destination has, to date, had very little experience with tourism, particularly as poverty and conflict have meant that the majority of Timorese have not had the opportunity to travel overseas. This limits individuals' experience with providing the level of service and hospitality that Western tourists expect. As many stakeholders noted, for many Timorese work is presently a means of income, not a career as such, and therefore building up the necessary skills required for the tourism industry has been very rare. As a stakeholder in private-sector tourism explained to me: "Balinese, they live, they were born as hospitality industry people. It's created by nature. Timorese, they were born, they live as a warrior. It's created by nature. Is it their fault, no, the situation is like that. But how do we change it?" (interview, Dili, Dec 20I3).

Timor-Leste also has a strong history of resilience-from its colonial past to World War II and, more recently, surviving a twenty-four-year occupation by Indonesia. During the Indonesian occupation, Timorese rallied support from across the world. It was not only freedom fighters in the jungle or families in prisons and villages who resisted; it was also those lucky enough to escape to Australia, Portugal, or other countries who promoted the struggle internationally and who helped Timor-Leste to finally achieve independence after twenty-four years. In interviews, various stakeholders described this as a defining aspect of Timorese identity. As one put it: "The way we fought this war was very strong. We used the media to actually get this place going. It was not just the guys here, but we were working outside; everything that we did outside was about the news. We wanted people to see it. We only had to close our eyes and close our 
ears, and just forget about it, but then we would've had a few more years to go. We always aimed for the maximum, we didn't aim for small, always the maximum" (interview, Dili, Dec 2013). Such a history makes Timorese people proud, passionate, and resilient-traits that all stakeholders spoke of with pride and said they wanted to see promoted in a marketing campaign. At the same time, it is this history that explains why Echtner and Prasad's "myth of the unrestrained" (2003) - in which tourists expect to enjoy the hospitality of smiling, submissive hosts—could never be applied to the promotion of Timor-Leste. As a stakeholder in private-sector tourism told me: "Timorese people have strong reasons for the way they are, and people have to come here and really understand what these people have been through. It gets into your blood. Things that you witness, that happen to your family" (interview, Tibar, Jan 2014).

On the other hand, while Timorese may have had limited experience with tourism and hospitality, several respondents suggested there is a "realness" and openness in the way that Timorese people welcome visitors. This does not necessarily equate to five-star service at restaurants but is rather an honest and hospitable nature that is welcoming to tourists. An expatriate stakeholder working for a local NGO explained: "You can walk into any village or neighborhood in Timor-Leste and the first thing people do is offer you a seat, and probably give you a coffee. You can't teach that. It's just an instinct" (interview, Dili, March 20I 5). It is such genuine local hospitality and the genuine nature of Timor-Leste and its people that most stakeholders urged me to promote. Ultimately, I learned that stakeholders wanted to see Timorese promoted as a proud nation, not as a people willing to be subservient to international visitors. We therefore ensured that the themes of pride and resilience were promoted in the campaign imagery, while also ensuring Timorese people were still depicted as friendly and welcoming.

\section{The Promotion of a Personality}

One of the most difficult challenges for marketers is to develop a campaign that makes a destination "live" and allows visitors to feel the authenticity of a unique place (Morgan, Pritchard, and Piggot 2003). While understanding that the promotion of paradise, culture, and people was important, I also wanted to represent the more intangible attributes of the destination-in other words, its unique personality. To me, the idea of portraying a destination and its people ran far deeper than simply depict- 
ing smiling locals on beautiful shores. I therefore held a workshop in Dili where I asked stakeholders what words they would use to describe TimorLeste as if it were a person, so as to allow for an intangible and emotive picture of Timor-Leste as a destination to emerge. In what follows, I have interspersed stakeholder quotes with my own words to develop a "personality story" for the nation of Timor-Leste. ${ }^{4}$

Stakeholders told me that their country is young and beginning to grow and develop in a new era. As one government respondent explained: "It's a person that's learning to live again." The nation is portrayed as youthful, vibrant, and stimulated to learn, particularly as the younger generations begin to distance themselves from the history of trauma. A local stakeholder working in tourism education told me, "There are new hopes, new dreams; people are wanting to go outside to the world, and to bring the world in," while another working in the Ministry of Tourism said: "There is excitement in finally freeing ourselves from the shackles of colonization and occupation."

Other stakeholders looked to the country's present, arguing that as the nation grows it is becoming a teenager, gradually maturing, though still somewhat cheeky and rebellious. As one respondent from privatesector tourism put it: "We're pushing boundaries, living the day." Despite the positive outlook and youthfulness, the country is still very wild and "rough." A second private-sector respondent suggested: "We have had hundreds of years and we are still wild. But we are moving too fast; we are losing the steps, and we may fall down." The wildness is a result of years of war, so people perceive that many Timorese are still easily angered. As one NGO stakeholder explained: "All these years we have fought, we've had hunger, we don't know if we have tomorrow." Yet, underlying the ruggedness and pain lie softheartedness and good intentions. A government respondent told me: "We are tough in action, but soft in heart."

Other stakeholders suggested that behind the wariness there is the desire for positive change and development. As a private-sector stakeholder explained: "We were a warrior, and we are still a warrior, because that's what we know. But please be patient; we want to change." There is also a strong sense of forgiveness in the country's personality and its people. "Through twenty-five years with Indonesia, what Indonesia has done, yet today we live together peacefully, hand by hand. There is peace in our heart," explained a government stakeholder. Today, the country stands dignified, proud, sometimes a little hesitant, but humble and welcoming: "We are a tall person, with a humble personality and our doors open to 
everyone. But we have a sign that says: If you come as a friend, come in, if you come to do something else, please don't bother!"

Local stakeholders suggested that the unique personality of Timor-Leste must be portrayed when marketing internationally. The nation must be perceived as friendly and welcoming, given the negative media coverage that has been circulated internationally for decades. However, at the same time, Timor-Leste must be portrayed as unpolished and raw to honestly depict the current situation-the nation is not a tourism paradise, nor should it be marketed as such. An NGO stakeholder discussed this issue with lyrical simplicity: "Timor-Leste is a girl or guy standing up and saying 'this is how I feel.' Humble about things. I don't have a big place in here, just sit on the floor with me and we sip some coconut juice or something and one day I might buy a proper seat so we can sit together, but for now sit with me on the floor under the coconut tree. Let's have a simple coconut juice." It is the pride, resilience, and modesty of Timorese culture that I took with me from the focus group. And it was with these valuable insights that I began to develop the marketing campaign.

\section{Development of a Campaign Slogan}

Throughout the five years of my research, I held further stakeholder workshops to discuss how to turn a "sense of place" into a stakeholder-led marketing campaign. During the workshops, I analyzed how local stakeholders wanted to see beaches and the idea of paradise promoted as part of the marketing campaign, while avoiding a $3 \mathrm{~s}$ approach to marketing. We talked about culture and the potential erosion of that culture through tourism. Importantly, I learned that Timor-Leste had to be represented as more than just a static destination, but as a place with a personality and genuine, local hospitality. I needed to portray the "authenticity" of TimorLeste and the Timorese-despite this very concept being a near impossibility when developing a marketing campaign targeted at Western tourists. In attempting to portray authenticity, I was cognizant of the fact that tourism ultimately banks on the commercialization of "authentic" places, people, and experiences (Bunten 2008) and that the idea of "cultural authenticity" is often no more than a merchandising device (Swanson and DeVereaux 2017).

We also looked for a destination slogan that would lead the campaign. Indeed, one of the most powerful elements of a marketing campaign is its slogan, as slogans provide an easy "hook" or "handle" to help consumers 
grasp the essence of the campaign (Lee, Liping, and O'Leary 2006). During the workshops a popular slogan was: "Come see us as we are ..." This slogan rests on both the cultural and undeveloped nature of Timor-Leste, admitting the destination is still intrepid, and does not offer first-class infrastructure or hospitality. At the same time, it suggests a travel experience that is not packaged or commodified.

While the majority of stakeholders embraced the slogan as their own, two local stakeholders working for Timorese NGOs raised concerns. Although they felt that the slogan captured Timor-Leste's unique tourism product and "personality," they pointed out that "Come see us as we are ..." could also be seen to differentiate the local inhabitants of Timor-Leste from potential Western tourists and imply they are a spectacle "to be seen." A colonial paradigm of a timeless present or the "myth of the unchanged" (Echtner and Prasad 2003) was articulated by a local education stakeholder when he asked: "How do we capture where we are going?" (stakeholder workshop, Dili, March 20I4). By this he meant that he wanted to see Timor-Leste's proud present and future possibilities, and not just its past, promoted in the campaign. While Timorese are still largely agricultural people, with 63 percent of households engaged in agriculture production and 80 percent rearing livestock (Timor-Leste Ministry of Finance 20I0), the nation is moving toward participation in global industries and economic development and does not necessarily want to base its future on its "timeless present." A government respondent argued, "This is not a theme park, it's a country, and Timorese people have a right to modernity" (interview, Dili, Nov 20I3).

As a result of the interview and focus group discussions, I proposed to stakeholders that the slogan was potentially reinforcing a colonial paradigm, which the nation may wish to avoid. Alternative suggestions were considered, such as: "Come meet us as we are ..." or "Come visit us as we are ..." to indicate a more mutually beneficial relationship and remove the idea of the Timorese people being "on display" to Western tourists. However, despite the objections, it was agreed by the stakeholder contingent that the originally proposed slogan should remain for the mock campaign (figure $\mathrm{I}$ ). ${ }^{5}$

Following the success of the mock campaign, the Asia Foundation funded the development of an official destination marketing campaign, which was additionally supported by the Timor-Leste Ministry of Tourism and guided by my research. Further stakeholder workshops were conducted during which a new slogan, "Explore the Undiscovered," was 
proposed. It was extremely well received by the stakeholder contingent, most particularly by the director of marketing at the Ministry of Tourism, who expressed a strong desire to promote Timor-Leste's natural beauty, especially when compared to its crowded Asian neighbors. He explained: "The slogan says: Visit Timor-Leste, because here we have something else you never have in the world" (interview, Dili, May 2016).

While the slogan avoids marketing a tourist experience that is staged for visitors or promises hosts who are smiling and submissive, I suggested it was again representative of a colonial typology, in this case, the "myth of the uncivilized" - a trope that represents tourism as an expedition into a destination beyond the furthest frontiers (Echtner and Prasad 2003). However, for the vast majority of stakeholders, the slogan captured exactly what they wanted in a marketing campaign: that the nation was real, raw, and that finally, after a long occupation, it was ready to welcome tourists. My overriding aim was to develop a marketing campaign led by the Timorese and developed for the Timorese, and "Explore the

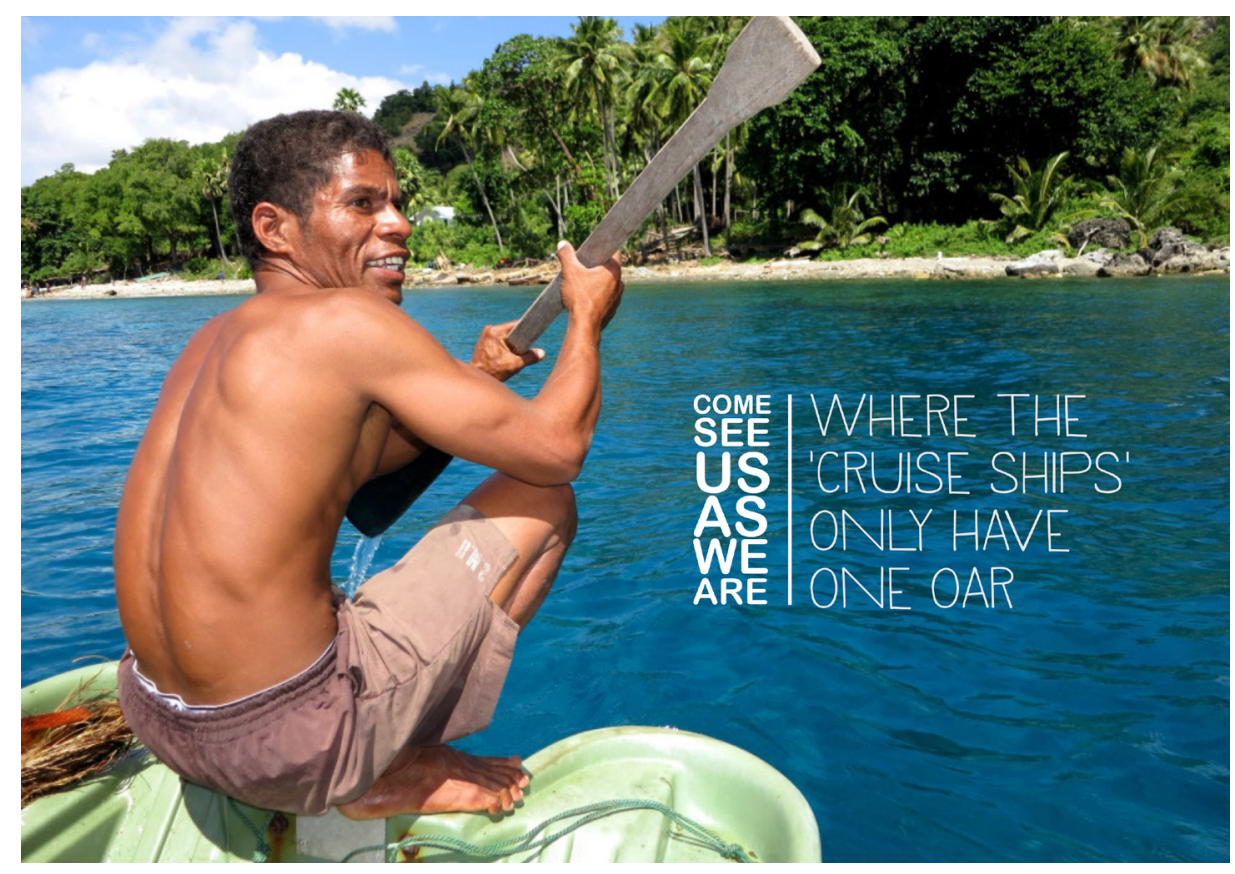

FIGURE I Where the "cruise ships" only have one oar: image from the proposed marketing campaign for Timor-Leste (20I4; full set of slides available at https://speakerdeck.com/naroman/come-see-us-as-we-are). Photo: Sara Currie. 
Undiscovered" represented the wishes of the Timorese community and their desire for tourists to begin to explore their undiscovered nation. The slogan was presented to the minister of tourism in late 2016 and approved by the Council of Ministers in May 2017.

At time of writing, the new marketing campaign is being developed; it will include a brand logo, graphic elements, and new imagery that depict Timor-Leste's sense of place. It is hoped this campaign will be the beginning of a new era of tourism growth for Timor-Leste and that the marketing campaign will lead a sustainable and ethical approach to promoting the island nation.

\section{Future Directions}

Echtner and Prasad argued that by identifying the colonial underpinnings of destination marketing we can begin to explore the paths to resistance (2003). In this article, I have attempted to highlight the views, ideas, and aspirations of Timorese tourism stakeholders in order to develop a stakeholder-led destination marketing campaign. Together with passionate destination stakeholders in Timor-Leste, I sought to find strategies to avoid the commodification of paradise and to promote the destination as being steeped in culture and history, as well as belonging to a proud and resilient people. Indeed, destination marketers have an important responsibility. Marketers hold considerable power over the destinations they promote, and therefore it is imperative we find ways to promote island nations ethically and sensitively so as to not depict a colonial paradigm and commodify a nation's people, culture, and "paradise" merely for tourist consumption.

Moving forward, the challenge for Timor-Leste in developing its tourism industry will not lie in the delivery or implementation of any one marketing campaign. Political will, budget, and stakeholder coordination will be paramount, alongside the improvement of Timor-Leste's other features including infrastructure, cost, and accessibility. Importantly, however, our work to date has shown that marketing a developing island nation can indeed begin "from within" and be led by the aspirations, ideas, and sense of place as articulated by its stakeholders. In this way, I hope the promotion of Timor-Leste can contribute to the scholarship on sensitive and ethical marketing in other developing island nations. 
I WOULD LIKE TO THANK the many people who provided valuable insights and feedback on this article-most particularly Marie Thorpe, Professor Michael Leach, an anonymous reviewer, and TCP editorial staff members Alexander Mawyer, Jan Rensel, and Zakea Boeger. Special thanks to Kalissa Alexeyeff and Siobhan McDonnell for developing this special edition and for their endless patience and advice throughout the publication process. This work would not have been possible without the support of my Timorese friends and colleagues and the passionate tourism stakeholders in Timor-Leste.

\section{Notes}

I Timor-Leste has attempted a variety of tourism marketing campaigns since independence. The slogan "Land of Discovery" was successfully launched in 2002; however, a new minister for tourism chose to replace it with the "Turismo Timor-Leste" logo, developed by a Portuguese agency, in 2005. The logo was infrequently and inconsistently used and, although the Ministry of Tourism developed a new logo in 2OI2, it was intended to brand the ministry as opposed to the country. While these logos have been utilized sporadically, none have been underpinned by a strategic marketing campaign.

2 In writing this article, I comment on my own position within the discoursethat I am ultimately an "outsider" looking to develop a marketing campaign for a country I have lived in only briefly. Throughout this work, therefore, I use many quotes verbatim to ensure the opinions of the Timorese are at the forefront.

3 The lingua franca and national language of Timor-Leste is Tetum, sometimes called Tetun, and is an Austronesian language influenced by Portuguese.

4 The workshop referenced here was conducted in March 20I4 at the Ministry of Tourism, Timor-Leste, to ascertain stakeholder views on the destination's personality and unique attributes, so as to be used toward the development of a marketing campaign. All quotes come directly from this workshop, unless otherwise stated.

5 To view the campaign, please see: https://speakerdeck.com/naroman/come -see-us-as-we-are

\section{References}

Alexeyeff, Kalissa

2016 Re-Purposing Paradise: Tourism, Image and Affect. In Touring Pacific Cultures, edited by Kalissa Alexeyeff and John Taylor, 403422. Acton, АCT: ANU Press. 
Amoamo, Maria

2007 Māori Tourism: Image and Identity-A Postcolonial Perspective. Annals of Leisure Research Io (3-4): 454-474.

Bunten, Alexis

2008 Sharing Culture or Selling Out? Developing the Commodified Persona in the Heritage Industry. American Ethnologist 35 (3): 380395 .

Buzinde, Christine N, David Manuel-Navarrete, Eunice Eunjung Yoo, and Duarte Morais

2010 Tourists' Perceptions in a Climate of Change: Eroding Destinations. Annals of Tourism Research 37 (2): 333-354.

Carr, Anna, Lisa Ruhanen, and Michelle Whitford

2016 Indigenous Peoples and Tourism: The Challenges and Opportunities for Sustainable Tourism. In Sustainable Tourism and Indigenous Peoples, edited by Anna Carr, Lisa Ruhanen, and Michelle Whitford. Special Issue of Journal of Sustainable Tourism 24 (8-9): I067-I079.

CAVR, Commission for Reception, Truth and Reconciliation in East Timor

2005 Chega! The Report of the Commission for Reception, Truth and Reconciliation (CAVR) Timor-Leste. Dili, Timor-Leste: CAVR.

CIA, Central Intelligence Agency

2017 Timor-Leste. https:/www.cia.gov/library/publications/the-world -factbook/geos/tt.html [accessed 4 May 20I7]

Cocks, Rodney

20I I Timor-Leste (East Timor). Third edition. Singapore: Lonely Planet Publications.

Conservation International

2018 Timor-Leste's Nino Konis Santana National Park. http://www .conservation.org/projects/Pages/Timor-Leste-Nino-Konis-Santana -National-Park.aspx [accessed 7 March 2018]

Cornelissen, Scarlett

2005 Producing and Imaging "Place" and "People": The Political Economy of South African International Tourist Representation. Review of International Political Economy I2 (4): 674-699.

d'Hauteserre, Anne-Marie

20 I Politics of Imaging New Caledonia. Annals of Tourism Research 38 (2): $380-402$.

Dinnie, Keith

2008 National Branding: Concepts, Issues, Practice. Oxford: Elsevier.

Echtner, Charlotte M, and Pushkala Prasad

2003 The Context of Third World Tourism Marketing. Annals of Tourism Research 30 (3): 660-682. 
Engelhardt, Richard A

2005 Culturally and Ecologically Sustainable Tourism Development through Local Community Management. In Culture and Sustainable Development in the Pacific, edited by Antony Hooper, I74-I86. Canberra, АСт: Asia Pacific Press.

Harrison-Walker, L Jean

$20 \mathrm{I}$ S Strategic Positioning of Nations as Brands. Journal of International Business Research Io (2): I35-I47.

La'o Hamutuk

2013 Annual Report. La'o Hamutuk. Dili, Timor-Leste: Timor-Leste Institute for Development Monitoring and Analysis.

Lee, Gyehee, Cai A Liping, and Joseph T O'Leary

2006 WWW.Branding.States.US: An Analysis of Brand-Building Elements in the US State Tourism Websites. Tourism Management 27 (5): 8I 5 828 .

Lloyd, Kate, Sandie Suchet-Pearson, Sarah Wright, Matalena Tofa, Claire Rowland, Laklak Burarrwanga, Ritjilili Ganambarr, Merrkiyawuy Ganambarr, Banbapuy Ganambarr, and Djawundil Maymuru

20I 5 Transforming Tourists and "Culturalising Commerce": Indigenous Tourism at Bawaka in Northern Australia. The International Indigenous Policy Journal 6 (4): 6.

MacCarthy, Michelle

2016 Making the Modern Primitive: Cultural Tourism in the Trobriand Islands. Honolulu: University of Hawai'i Press.

Morgan, Nigel J, Annette Pritchard, and Rachel Piggott

2003 Destination Branding and the Role of the Stakeholders: The Case of

Olins, Wally

New Zealand. Journal of Vacation Marketing 9 (3): 285-299.

2005 Making a National Brand. In The New Public Diplomacy: Soft Power in International Relations, edited by Jan Melissen, I69-I80. New York: Palgrave Macmillan.

Pratt, Stephen

2013 Same, Same but Different: Perceptions of South Pacific Destinations among Australian Travelers. Journal of Travel and Tourism Marketing 30 (6): 595-609.

Rajalingam, Gobie 20142014 Survey of Travelers to Timor-Leste. Dili, Timor-Leste: The Asia Foundation.

Roberts, Sherma, and Acolla Lewis-Cameron

2010 Small Island Developing States: Issues and Prospects. Marketing Island Destinations: Concepts and Cases, edited by Acolla LewisCameron and Sherma Roberts, I-IO. Amsterdam: Elsevier. 
Rogal, Maria

2OI2 Identity and Representation: The (Yucatec) Maya in the Visual Culture of Tourism. Latin American and Caribbean Ethnic Studies 7 (I): 49-69.

Santos, Edson Redy Moreira dos, and María Lorena Rodríguez Campo

2014 Destination Branding: A Reflective Analysis of Brand Cape Verde. Place Branding and Public Diplomacy Io (I): 87-102.

Sinclair-Maragh, Gaunette, and Dogan Gursoy

2015 Imperialism and Tourism: The Case of Developing Island Countries. Annals of Tourism Research 50:I43-I 58.

Stronza, Amanda

2008 Through a New Mirror: Reflections on Tourism and Identity in the Amazon. Human Organization 67 (3): 244-257.

Swanson, Kristen K, and Constance DeVereaux

2017 A Theoretical Framework for Sustaining Culture: Culturally Sustainable Entrepreneurship. Annals of Tourism Research 62:78-88.

Tamaira, A Mārata

2016 Native Realities in an Imaginary World: Contemporary Kanaka Maoli Art at Aulani, A Disney Resort and Spa. In Touring Pacific Cultures, edited by Kalissa Alexeyeff and John Taylor, I67-I8I. Acton, ACT: ANU Press.

Timor-Leste Department of Immigration

2017 List of Foreigners Coming to East Timor 201 I-2016. Dili, TimorLeste.

Timor-Leste Government

20I I Strategic Development Plan 20I I-2030. http://timor-leste.gov.tl/wp -content/uploads/20 I I/o7/Timor-Leste-Strategic-Plan-20 I I-2030I. pdf [accessed I March 20I8]

Timor-Leste Ministry of Finance

20I0 Highlights of the 2010 Census: Main Results in Timor-Leste. TimorLeste: Ministry of Finance.

Trindade, Jose "Josh"

2012 Lulik: The Core of Timorese Values. In Timor-Leste Studies Association, edited by Michael Leach, N C Mendes, A B d Silva, B Broughton, and A d C Ximenes, I6-29. Dili, Timor-Leste: Swinburne University.

Weaver, David

2010 Indigenous Tourism Stages and Their Implications for Sustainability. Journal of Sustainable Tourism I 8 (I): 43-60.

Yang, Li

20II Ethnic Tourism and Cultural Representation. Annals of Tourism Research 38 (2): 56I-585. 
Yang, Li, and Geoffrey Wall

2009 Authenticity in Ethnic Tourism: Domestic Tourists' Perspectives.

Current Issues in Tourism I 2 (3): 235-254.

\section{Abstract}

When marketing an island destination for tourism, ethical and moral issues must be considered, particularly given that the way in which a nation is promoted can have a profound impact on its residents and the type of tourism and tourists it attracts. In this article, I examine this challenge as it is faced by Timor-Leste, a young island nation attempting to grow its tourism sector. I investigate the possibility of developing a marketing campaign that avoids the commodification of paradise and, instead of adopting a " $3 \mathrm{~s}$ " (sun, sea, and sand) approach to marketing, begins from a "sense of place" as understood by local residents, through analyzing their desired representations of paradise, culture, people, and personality. The article concludes with describing a marketing campaign developed in collaboration with tourism stakeholders in Timor-Leste that demonstrates the potential for an Indigenous stakeholder-led approach to marketing an island nation.

KEYWORDS: tourism, Timor-Leste, ethical marketing, marketing island nations, paradise, Indigenous tourism 